\title{
ОБРАЗ ЖІНКИ В ОЦІННИХ ФРАЗЕОЛОГІЧНИХ ОДИНИЦЯХ УКРАЇНСЬКОЇ МОВИ: ГЕНДЕРНИЙ АСПЕКТ
}

\author{
МАРІЯ ЧЕТИРБА \\ Університет імені Адама Міцкевича, Познань - Польща \\ OBRAZ KOBIETY \\ W WARTOŚCIUJĄCYCH JEDNOSTKACH FRAZEOLOGICZNYCH \\ JEZZYKA UKRAIŃSKIEGO: ASPEKT GENDEROWY
}

\section{MARIA CZETYRBA}

Uniwersytet imienia Adama Mickiewicza w Poznaniu, Poznań — Polska

STRESZCZENIE. W artykule dokonano analizy obrazu kobiety w ukraińskiej frazeologii. Zbadano wpływ stereotypu na kształtowanie się kategorii oceny.

\section{THE IMAGE OF A WOMAN \\ IN UKRAINIAN EVALUATIVE PHRASEOLOGICAL UNITS: GENDER ASPECT}

\author{
MARIA CZETYRBA \\ Adam Mickiewicz University in Poznań, Poznań - Poland
}

ABSRACT. The article focuses on the analysis of peculiarities of a woman characteristics in Ukrainian phraseology. The role of stereotype in the process of formation of gender evaluation has been investigated.

B

останні роки помітно підвищився інтерес мовознавців до вивчення гендерної лінгвістики, передусім у проекції на лексику й фразеологію. О. Бєссонова, А. Мартинюк, О. Горошко, О. Козачишина, А. Шиліна, О. Холод, А. Архангельська та інші вчені вже тривалий час досліджують гендерну проблематику, вивчаючи мовні явища в культурологічному, соціологічному та психологічному аспектах. Одним із стимулів активізації гендерних досліджень $\epsilon$, безперечно, перспективність гендерної парадигми наукових знань, у якій, на думку І. Халєєвої, „переплітаються” різні науки про людину, не лише щодо її біологічних, але й соціально та культурно обумовлених характеристик ${ }^{1}$. Адже гендер визначають як „елемент сучасної наукової моделі людини, що відбиває соціокультурні аспекти статі, які фіксуються в мові”". Він став „одним iз параметрів людської особистості, що включає не тільки стать як біологічну субстанцію, але і як культурно зумовлений розумовий конструкт"з. Однак, як зауважує I. Ольшанський, гендер не є лінгвістичною категорією, а його зміст

${ }^{1}$ И. И. Халеева, Гендер в теории и практике обучения, [в:] Доклады Первой международной конференции “Гендер: язык, культура, коммуникация”, Москва 2001, с. 7.

${ }^{2}$ А. В. Кир илина, Гендерные аспекты языка и коммуникации, дис. докт. филол. наук, Москва 2000, с. 12.

${ }^{3}$ О. Л. Бєссонова, Оиінний тезаурус англійської мови: когнітивний $і$ гендерний аспекти, дис. докт. філол. наук, Донецьк 2002, с. 11. 
можна розкрити тільки шляхом аналізу мовних структур 4 . Саме розвиток когнітивної лінгвістики сприяє усвідомленню антропоцентричності мовного знака, а введене наукою поняття соціальної категоризації дало можливість відповідно сегментувати соціальний світ на соціальні категорії та групи, де гендер як соціальний конструкт, що відображає сукупність соціальних й культурних норм, очікувань та уявлень стосовно особи чоловічої та жіночої статей, трактують як соціокультурну категорію.

У цьому дослідженні розглядаємо оцінну складову, що міститься в семантичній структурі фемінно маркованих фразеологічних одиниць.

Сучасна наука репрезентує розмаїття поглядів на тлумачення категорії оцінки. Загалом у свідомості людини вона, як відомо, існує у вигляді опозицій „добре - погано” чи „позитивне - негативне”. 3 позиції логіки це „мисленнєвий акт, унаслідок якого висловлюється позитивне чи негативне ставлення суб'єкта до оцінюваного об'єкта на основі його порівняння з обраним еталоном"5. Мовознавчі дослідження не презентують однозначних поглядів щодо тлумачення категорії оцінки. Одні вчені (Т. Матвєєва, Т. Вендіна) приєднуються до логіко-філософської інтерпретації поняття оцінки, розглядаючи іï як наслідок співвіднесення мовцем будь-якого поняття з загальноприйнятими уявленнями про норму на основі дихотомії „добре - погано”. Інші дослідники під час осмислення мовного змісту оцінки необхідним уважають виокремлення двох чинників: динамічного - оцінку-процес та статичного - оцінкурезультат, що замикаються в смисловому потенціалі слова. На думку М. Ляпон, „оцінка - це, з одного боку, процес оцінювання, тобто розумова процедура, операція, умовивід чи емоційний імпульс, а з іншого, - ситуація, акт, що фіксує наслідок цієї процедури"”.

У семантичному плані категорія оцінки „передбачає ціннісний аспект значення мовних висловлювань, який можна інтерпретувати так: А (суб'єкт оцінки) вважає, що Б (об'єкт оцінки) хороший - поганий”. Т. Маркелева трактує оцінку як лексико-семантичну категорію, де „мовна семантична інтерпретація змісту оцінки передбачає аспекти поєднання денотативних і конотативних елементів значення та імпліцитних й експліцитних змістових елементів. Вони виражаються в складному взаємозв'яку дескриптивного та власне оцінного значень".

Як бачимо, категорія оцінки тісно пов'язана з образом людини в мові, хоч значення оцінки, репрезентоване в тлумачному словнику, вважають гендерно нейтральним, оскільки, як зауважує О. Бєссонова, „опозиція чоловіче - жіноче, семантична структура конструентів якої зумовлена культурними міркуваннями, природними фактами, виявляється на парадигматичному рівні в семантиці

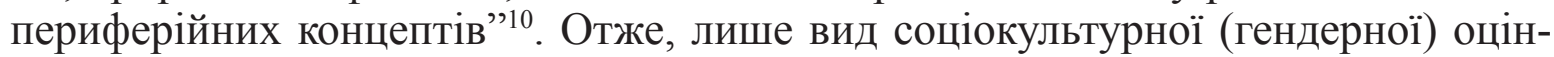

${ }^{4}$ И. Г. Ольшанский, Гендер: лингвистические аспекты, [в:] “Филологические науки”, Москва 2000, № 3, с. 133-136.

${ }^{5}$ I. Чобот, Оиінка як функиіонально-семантична категорія, [в:] "Нова філологія", Запоріжжя 2002, № 3 (14), с. 131-132.

${ }^{6}$ Т. В. Матвеева, Функциональные стили в аспекте текстовых категорий. Синхронносопоставительный очерк, Свердловск 1990, с. 28.

${ }^{7}$ М. В. Ляпон, Смысловая структура сложного предложения и текст. К типологии внутритекстовых отношений, Москва 1986, с. 26.

${ }^{8}$ Е. М. Вольф, Функциональная семантика оценки, Москва 1985, с. 5.

9 Т. В. Маркелева, Функиионально-семантическое поле оценки в русском языке, [в:] "Вестник Московского университета”, “Филология”, сер. 9, 1994, № 4, с .12.

${ }^{10}$ О. Л. Бєссонов В, Оиінний тезаурус англійськой мови: когнітивний $і$ гендерний аспекти, дис. докт. філол. наук, Донецьк 2002, с. 234. 
ки суб'єкта та об'єкта навколишньої дійсності, підставою якої є базова ознака „чоловіче” чи ,жіноче”, дає можливість розкрити механізм оцінної номінації в гендерно маркованих фразеологічних одиницях. За іiї допомогою відображається система цінностей чоловіків та жінок в їх особистому (внутрішньому) та суспільному (зовнішньому) житті. При такому підході актуальною вважаємо думку Н. Арутюнової стосовно того, що „оцінка належить до числа власне людських категорій. Її визначає фізична та психічна природа людини, іiї буття та відчуття, вона передбачає їі мислення та діяльність, ставлення до інших людей та предметів дійсності, ії сприйняття мистецтва" ${ }^{11}$. Таким чином, унікальність оцінки полягає в іiі здатності не лише відображати ціннісну сутність об'єкта для суб'єкта, а й формувати світогляд щодо поведінкових стереотипів людей ${ }^{12}$. Основу гендерної оцінки складають саме особливості мислення чоловіків та жінок, що відображені в гендерних стереотипах. Ці стандартні та узагальнені думки етносу щодо характеристик обох статей не лише розкривають зміст самого стереотипу, але й репрезентують його оцінний характер. Стереотип як результат соціольно-історичного досвіду суспільства визначає зміст різних соціальних категорій, зокрема й гендерної оцінки. Отже, в гендерному аспекті оцінка регулює норми та цінності, відведені суспільством жінкам та чоловікам.

Загальновідомо, що фразеологічні одиниці як „дзеркало життя нації” спрямовані на суб'єкт, і тому оцінна складова є невід'ємною частиною семантики чималої кількості гендерних фразеологічних номінацій, відображаючи ціннісні „пріоритети” окремої статі, що зафіксовані в менталітеті українського суспільства. Щоправда, згідно з думками вчених, у фразеологізмах оцінка має не суб'єктивний і не об'єктивний характер, а прагматичний ${ }^{13}$, оскільки між предикативною ознакою та об' єктом, якому цю ознаку приписують, стоїть регулятивна постать людина. „Для того, щоб оцінити об'єкт, людина повинна пропустити його крізь себе. Оцінка репрезентує людину як суб'єкт, на який звернений світ"14. Адже аксіологічне оцінювання об' єкта в гендерно маркованих фразеологічних одиницях, на думку А. Архангельської, відбувається через зв'язок між ціннісною орієнтацією номінатора (суспільства або соціальної особистості) і номінанта (властивістю, характеристикою чоловіків або жінок), що оцінюється позитивно чи негативно на певній підставі відповідно до „стандарту” предметів чи їх стану в концептуальній картині світу, що лежать в основі норм оцінки ${ }^{15}$.

Гендерно марковані фразеологічні одиниці на позначення жінки активно репрезентують в українській мовній картині світу три головні параметри: „Зовнішність”, „Внутрішні якості” та „Соціальна характеристика”.

Параметр „Зовнішність” загалом асоціюється за зовнішнім виглядом жінки й містить номінації, що стосуються вроди, привабливості, одягу, віку, напр.: моя жіночка як картиночка; як мак цувіте; як лялечка; гарна, хоч з лиця води напитися; як зелена травка.

У менталітеті кожної нації зафіксовано свій ідеал жіночої краси. Найчастіше однак його репрезентують означення за такими параметрами, як „вродли-

${ }^{11}$ Н. Д. Арутюнова, Аксиология в механизмах жизни и языка, [в:] Проблемы структурной лингвистики, 1982, под ред. В. П. Григорьева, Москва 1984, с. 5.

${ }^{12}$ В. Кон он енко, Мовна оцінка в етнокультурному аспекті, [в:] IV Міжнародний конгрес украӥністів, Мовознавство, за ред. В. Німчука, Київ 2002, с. 172.

${ }^{13}$ Н. Д. Арутюнова, Зазнач. праця, с. 9.

${ }^{14}$ Н. Д. Арутюнова, Язык и мир человека, Москва 1996, с. 181.

${ }^{15}$ А. М. Архангельська, Ономасіологічна парадигма „чоловік” у чеській та украӥнській мовах, дис. докт філол. наук, Рівне 2008, с. 107. 
ва” - „невродлива” чи „приваблива” - „неприваблива”. Безсумнівно, в системі ціннісних орієнтирів жіночу красу розглядають як добро та благо.

Найчастотнішим складником фразеологізмів, що вербалізують похвалу жіночої вроди є лексема „квітка”, напр.: гарна як квітка на весні; гарна як квітка у полі; пишна квітка; квіточка вранці; як квіточка. У таких фразеологізмах джерелом узагальненої сигніфікації оцінки є сама оцінна сема в буквальному значенні компонента, що поширює оцінне значення на всю фразеологічну одиницю. Аспект порівнання у зворотах лише контекстуально інтенсифікує меліоративність образу еталона.

Українське суспільство приділяє велику увагу „естетиці стрункості” жінки й тому, як зауважує Н. Зборовська, виявляється вона наскрізним мотивом характеристики особи жіночої статі ${ }^{16}$. За названою ознакою українські оцінні фразеологізми також конструюють модель гендерної ідентичності жінки. У народі за стереотипним образом стрункої, тендітної, гарної жінки закріпилося багато фразеологізмів, складником яких є фітонім. Насамперед українське суспільство позитивно оцінює рослинний світ відповідно до архетипів української натурфілософії, проводяться паралелі жінки з калиною, тополею чи березою, напр: дівчина - як у лузі калина; дівка - як тополя; тонка як тополя; як біла берізка; дівчина як берізка; як ивіт калини. Загалом калина та береза асоціюються в українському етносі не лише зі стрункістю. Червоні ягоди калини символізують сонце (життя і світло), вогонь, а сам червоний колір - це взагалі символ здорової, повносилої жінки ${ }^{17}$, а береза — „символ чистоти, світла, родючості, дівочої ніжності”" тичний символ жінки, але також ознака ії плодючості. У семантиці згаданих порівнянь ознака стрункості $є$ тотожною з фізичною красою жінки.

Як бачимо, врода жінки, яку вербалізують фітоніми, $є$ позитивно оцінною, а метафора, репрезентована відповідними іменниками, продуктивний образний засіб моделювання українських фразем. Проте, як зазначає О. Сінчак, „для характеристики некрасивої жінки рослинну символіку взагалі не використовують" $"$.

Частотними в структурі фразеологічної одиниці є також етнографічні слова-символи, конотативне значення яких позитивно забарвлене, напр.: як писанка; мов святкова крашанка; неначе великодня писанка. Цей національнокультурний компонент вза'ємодіє 3 оцінним в семантиці фразеологізмів та виразно проектує позитивний образ жінки.

У семантичному та оцінному аспектах фемінно маркованими $є$ астральні об'єкти, насамперед „зірка” та „сонце” У багатьох усталених виразах згадані лексеми розвинули позитивний спектр значень та вживаються на позначення красивої, вродливої жінки, порівн.: гарна як сонще; гарна як зірка на небі. Ці назви небесних реалій, зафіксовані у фразеологічних одиницях також у зменшено-пестливих формах: як зіронька; гарна як умите сонечко.

Українська фразеологічна картина світу для оцінного позначення зовнішньої характеристики жінки часто використовує анімалістичний компонент, напр.: яра бджілка; як киия з бантиком; гарна як лебідка; мов пава мальова-

${ }^{16}$ Цит. за: О. П. Сінчак, Зовнішній вигляд жінки як об'єкт фразеологічної репрезентаиії (тендерний аспект), [в:] "Ученые записки Таврического национального университета им. В. И. Вернадского”, сер. “Филология”, Симферополь 2005, т. 18 (57), № 1, с. 208.

${ }^{17}$ В. Жай воронок, Знаки української етнокультури, Словник-довідник, Київ 2006, с. 269.

${ }^{18}$ В. М. Войтов ич, Украӥнська міфологія, Київ 2002, с. 131.

${ }^{19}$ О. П. Сінчак, Зазнач. праця, с. 209. 
на. Однак у більшості порівнянь зооморфізми, на відміну від фітонімів, слугують для вираження негативної оцінки: жаба - то твоя баба; красива як собака (вівия) сива; така солодка як свиня в дощ; вродлива як сова; чорнобрива як руде теля; ряба корова; як зозуля водяна.

Негативно конотованими є також порівняння жінки 3 міфологемою “відьма": страшна як відьма; красива як відьма з Лисої гори; красива як відьма в коноплях.

Ознака невродливої, огрядної, товстої жінки вербалізується й у ряді фемінно маркованих предметів, об'єктів дійсності: баба як кошара; брудна як мазниия; баба як піч; баба як стодола; баба як фаса; здорова як хата; білолиия як мазниия; чорнобрива як сметана. Ототожнення жінки з предметом є домінантним в українській фразеології й тому вважається, що ,жінка - це предмет різного типу"20, негативно або позитивно маркований: струнка як свічка; веде себе як ганчірка.

Для оцінки привабливості жінки в українській культурі домінантним критерієм є, безсумнівно, краса (врода). Однак естетику жіночого вигляду вдало підкреслює іiі одяг. Зі смаком одягнену жінку порівнюють, наприклад, з царицею та панною: гарна мов циариця; гожа як панна. Такі порівняння експлікують жінку за соціальним станом.

Непривабливість одягу, неохайність жінки відображено в таких фразеологічних номінаціях: коза в сарафані; красива як свиня в коралах; Христя в намисті.

Отже, в концептосфері „Зовнішність” мотивами оцінки стали усі ознаки фізичної привабливості або непривабливості жінки як основа виміру їі жіночності. Зовнішня естетика жінки завжди сплітається з їі внутрішньою красою.

У цьому дослідженні за параметром „Внутрішні якості” виокремлено семантичні поля, що репрезентують жіночий характер (вдачу) та розум. Перше семантичне поле складають фразеологізми, що дають уявлення про головні стереотипізовані жіночі риси характеру. Стереотипи „слугують своєрідним дзеркалом відображення реальності, хоча й досить кривим ${ }^{21}$ ". Негативною оцінкою наділені такі внутрішні якості жінки, як балакучість, сварливість та язикатість: сорочин хвіст; відьма конотопська; язиката Текля; місцеве радіо; жінки як сороки; жінка хиба те утає, чого не знає.

Загалом негативне забарвлення містить і власне сама лексема „баба”, що фіксується в багатьох фразеологізмах, які віддзеркалюють негативні риси жіночої іпостасі: базарна баба; баба Параска (Палажка); дві баби торг, а три ярмарок.

Потребу жінки багатослівно виражати свої думки вчені вбачають у тому, що ,для жінки мова — це іiі зброя з усіма іï функціями — оборонятися, нападати, уражати" 22 Цей факт зокрема репрезентує фразеологізм жіночий язик гостріший від меча.

Отже, традиційно приписуваний жінці гріх „балакучості” пов’язують 3 „неінформативністю жіночої мови”23. Лексичне обличчя жіночого логосу,

${ }^{20}$ Г. Вальтер, В.Мокиенко, Новая жизнь древнейшей профессии, [в:] Слово. Текст. Время, к 60-летию проф. М. А. Алексеенко, Москва 2002, с. 98.

21 О. Л. Козачишина, Лінгвістичні прояви гендерних характеристик в англомовних художніх текстах (на матеріалі американської прози ХХ сторіччя), Київ 2003, с. 72.

22 Цит. за: Т. Сукаленко, Метафоричне вираження концепту „Жінка” в украӥнській мові, Київ 2010, с. 167.

${ }^{23}$ Т. Сукаленко, Зазнач. праця, с. 167. 
на думку Л. Ставицької, „пронизує емоція, яка поширюється на весь ії словник через інтонацію та експресивний синтаксис"24, тому для жінки не стільки важливо щъо сказано, скільки як. Культура регламентує жінці емоційне, колоритне, експресивне мовлення.

Центральною морально-етичною категорією, як відомо, є добро - вершинна людська цінність. Українська фразеологія в такому позитивному аспекті характеризує спокійну, вірну, господарну жінку: добрий ангел; погожа літня днина; смирна як ягниия; нема вірнішого приятеля, як добра жінка; дім держиться не на землі, а на добрій жіниі; добра жінка дім збереже.

В українській культурі позитивно конотованим є образ енергійної, веселої та діяльної жінки. Як уважає В. Жайворонок, „типова українська жінка - весела, балакуча, дуже рухлива й працьовита"25, порівн.: прудка як коза; грім-баба; молодиия як грім, козир-дівка.

Більшість оцінних фемінно маркованих паремій, що експлікують внутрішні якості, містить негативну оцінку. Недобра, зла та підступна (хитра) жінка, репрезентована в таких фразеологізмах: сердита як відьма; баба з пекла родом; оприскувата мов іскра; добра як з курки молоко, а з верби петрушка; посудина дияволова. Низько оцінюють також і розумові здібності жінки. Культура наділяє жінку „неповноцінністю інтелекту”: говари до неї, а у неї маковеї; добра кума та розуму нема; і вродилась, і виросла, а розуму не винесла; краса до віния, а розум до кіния. Образ жінки нерозумної чи обмеженої „інтелектуально”, зумовлений „історичними й соціокультурними факторами”26. Саме з чоловіком асоціювалося все, що пов'язане з розумом та логічним мисленням.

Атрибути жінки як прекрасної статі, суспільство вбачає в емоційності та чуттєвості. Таку гендерну асиметрію вербалізує відомий фразеологізм жіноча логіка. Адже приписувані жінці внутрішні негативні ознаки суголосні гендерним стереотипам жіночої вдачі, що відповідають традиційній характеристиці жінки.

Параметр „соціальна характеристика” жінки охоплює основні природні жіночі ролі, схильність жінки до материнства та сімейного життя. Щоправда, давні символи та цінності нашарувалися на новий, культурно зумовлений жіночий стереотип, але не змінили свого характеру. М. Рубчак уважає, що „сучасні українці схильні сприймати відроджені цінності як автентичні репрезентації стародавньої матріархальної української культури"27. Образ жінки як охоронниці, берегині домашнього вогнища експлікує незбагненно величезну силу її материнських почуттів, що в українській фразеології завжди позитивно марковане: любов матірня $і$ на віддалі гріє; без матері і сонце не гріє. Ознака материнства найчастіше втілена в ядерних семах „мама”, „матуся”, „ненька”. В. Агеєва наголошує, що власне „материнство давало жінці соціальний статус”28. „Ця роль $\epsilon$ атрибутом, що характеризує квінтесенцію української жінки й утілює ії автентичне буття в суспільстві”29.

Оцінну противагу „матері” створює образ-концепт „мачухи”, за яким закріплена негативна конотація: ознаки зла, лицемірства та егоїзму: чеше як

24 Л. Ставицька, Мова і стать, [в:] “Критика”, Київ 2003, № 6 (68), с. 31.

${ }^{25}$ В. Жайворонок, Зазнач. праця, с. 222.

${ }^{26}$ О. А. Чибишева, Концепт „Женщуина” в русской и английской фразеологии (на материале предметных фразеологизмов, именующих женщину), Челябинск 2005, с. 15.

${ }_{27}$ М. Рубчак, Християнська Богородиия чи Берегиня? Фемінізм на противагу вічно жіночому, [в:] “Філософська думка”, Київ 2000, № 1, с. 111.

${ }^{28}$ В. Авгеєва, Філософія жіночого існування, [в:] Друга стать, Київ 1994, с. 15.

${ }^{29}$ М. Рубчак, Зазнач. праця, с. 113. 
мачуха; жаліє діток як мачуха; мачуха сироті їсти зварила, а сама з 'їла; голівонька наша бідна, щзо в нас матінка нерідна; у вітчима чорт межи очима, а в мачухи - два.

Отже, фемінним за своєю природою є, очевидно, український образ світу як сімейно-родинного затишку. Концептосфера „Соціальна жінка” охоплює різноманітні соціально-рольові характеристики, зокрема жінка-дружина, кохана жінка, порівн.: нема кращого друга, як вірна супруга; ніхто так не догляне, як вірна дружина; добру жінку вз'яв - горя не зазнав.

Наголосимо також, що в українській мовній картині світу високо оцінюють жінку з огляду на іiї сексуальну привабливість: синє виноградне зернятко; солодка грушечка. Однак у фразеологічному фонді простежуємо й фіксацію негативного ставлення до жінки легкої поведінки, тобто жінки-повії, порівн.: нічний метелик; кара вавилонська; драна кішка. А це значить, що українське суспільство регламентує жіночу вірність, цнотливість, напр.: зелена трава; чиста квітка.

Висновкуємо, що образ-концепт жінки, який вербалізовано в українській фразеології, відображає низку гендерних стереотипів, що репрезентують узагальнені культурні уявлення про приписувані жінкам зовнішні, внутрішні та соціальні якості, характеристики. Гендерні стереотипи впливають на сприйняття та інтерпретацію жінки як соціокультурної статі. Оцінка, що зафіксована у фемінно маркованих фразеологічних одиницях, репрезентує типову аксіологію концептів культури, що їх містять також слова-символи української мовної картини світу. Наведені фемінно марковані фразеологічні порівняння, що передають певну стереотипізовану інформацію про жіноче начало, дають змогу адекватно оцінити етнічну жіночу іпостась. 